\title{
In the name of existence: Identity politics of the hare Krishna consciousness in Yogyakarta
}

\author{
Martinus Joko Lelono \\ Indonesian Consortium for Religious Studies, Universitas Gadjah Mada, \\ Gadjah Mada Graduate School Building, III-IV Floor, Jl. Teknika Utara, \\ Pogung, Yogyakarta, Indonesia 55281 \\ e-mail: martinusjoko@gmail.com
}

\begin{abstract}
What does normal mean? Referring to its meaning, normality is connected to the acceptance of people. According to Charles Taylor, it's about recognition. Certain people take the recognition for granted, while others need significant effort. In Indonesian context, there are some religions that need to do significant effort to be accepted as normal. The law on the official religions makes minority groups tends to adjust their beliefs to one of the official religion. This research is about the struggle of The Hare Krishna Community in Yogyakarta to be recognized. As a new religious movement that came to Indonesia in 1970s, in the middle of official religions in Indonesia, Hare Krishna community fights for their existence. This community did efforts for its acceptance within Balinese Hindu community and the society in general. They did three kinds of identity politics: the consolidation among them; the negotiation toward Balinese Hindu community; the union with society in general. By doing so, they need to negotiate their rites and some of their belief system to the official one. Since talking about the official religions is debatable, these efforts are also a part of looking forward for a more respectful society toward the minority. Their effort for the public recognition is a process of identity politics.
\end{abstract}

\section{Keywords}

adjustment, identity politics, Indonesia, official religion, religious freedom

\section{Introduction}

Citation: Lelono, M. J. (2018). In the name of existence: Identity politics of the hare Krishna consciousness in Yogyakarta. In M. Amini, M. Yusuf, \& V. I. Yulianto. (Eds.), UGM Digital Press Social Sciences and Humanities: Vol. 1. Proceeding of the 2nd International Conference on South East Asia Studies, (pp. 69-75).

Published: October, 2018
On its constitution at verse 29 , Indonesia guarantees the freedom of worship for each citizenship: (1) The State is based upon the belief in the One and Only God (2) The State guarantees all persons the freedom of worship, each according to his/her own religion or belief. In fact, Indonesia does not strictly follow this line. For example, Soeharto, the second President of Indonesia, banned the existence of Chinese belief and culture. It is recorded on the President Instruction Number 14/1967 about Chinese Religion, Belief, and Culture. On his instruction, Soeharto declared that Chinese religion, belief, and culture were banned to be shown in public in Indonesia. Following the instruction, 
there is a formal law Number 5/1969 about the ban on the declaration of Chinese religion, belief, and culture. The law also declared that Indonesian formal religions consist of Islam, Protestant, Catholic, Hinduism, Buddhism, and Confucianism. In fact, the regulation in the lower level does not acknowledge Confucianism as an official religion. The instruction of the Ministry of the home affair in 1974 mentions only Islam, Protestant, Catholic, Hinduism and Buddhism as the official religions. Just more than a quarter of a century, on his Instruction No. 6/ 2000, President Abdurrahman Wahid removed the ban.

During these 72 years of independence, Indonesia experiences a lot of violence against religion: the official, the minority, and also the unrecognized religion. In order to be accepted as 'official religion', religions that should adjust their existence with the official religion, since "the official religion has a broader space to express their religion, on praying and celebrating festivals. They got the support from the government for their existence (Hasse, Risakotta, \& Bagir, 2011, p.103). On the one hand, they appear as a part of the official religion, but on the other hand, their loyalty is belonging to their own belief that practically different from the official.

\section{Discussions}

\subsection{Hindu in General and Hindu in Indonesia}

According to Encyclopedia Brittanica, "Hinduism is a major world religion originating on the Indian subcontinent and comprising several and varied systems of philosophy, belief, and ritual." The name Hinduism is a relatively new term that used by British writers in the first decades of the 19th century. It refers to a rich cumulative tradition of texts and practices, some of which date to the 2nd millennium BCE or possibly earlier. In the early $21^{\text {st }}$ century, Hinduism had nearly one billion adherents worldwide and was the religion of about 80 percent of India's population. Despite its global presence, however, it is best understood through its many distinctive regional manifestations. Some argue that there is no singular or unitary religion of India at all. They regard Hinduism as an umbrella term for a multitude of related beliefs and practices, known as "margas." (Gold, et.al., 2017). June McDaniel emphasizes on the plurality of Hinduism in general and the particularity of Indonesian Hindu. McDaniel argues that Indonesian Hindu is different than those Hindu communities come from India. He mentions:

"My thesis is that Agama Hindu Dharma Indonesia is actually a new religious movement of a type different than those usually discussed in the literature. It is a government-sponsored, governmentgenerated religion with a moral and ethical focus, understood to be a modern adaptation of an ancient revelation. It has the major advantage of a new religion: it is rationalized, adapted to social and political needs, conforms to the national creed, and fits with structures of other government-approved religions."(McDaniel, 2010, pp.93-111)

Lanus did a research on the standardization of Hindu in Bali. He concludes that 'Balinese Hinduism' (Agama Hindu Bali) is now commonly regarded as a result of new format done by Balinese urban intellectuals and religious leaders. In another word, it is a result of negotiation with Western colonial authorities and missionaries in an early 20th century on the one hand, and state bureaucrats in postindependence Indonesia (Lanus, 2014, pp.243-272). The consequence of this standardization is that Hinduism that was not a dogmatic religion nowadays has a certain standard for its acceptance. At least there is a standard to claim as the real Hindu.

In Indonesia, the government has a significant influence on religion. Religion is controlled by the Department of Religious affair (Departemen Agama), the national department led by the Minister of Religious Affair, with headquarters in Jakarta and offices throughout Indonesia. On following its constitution, 'Belief in the One, Almighty God' (Kepercayaan Terhadap Tuhan Yang Maha Esa). President Sukarno, the first president of Indonesia, established the Ministry of Religious Affairs to handle any religious affairs in the state. They have an authority to influenced religious beliefs and practices in all over Indonesia. One of its influence is that they have authority to different religious communities into two groups, namely institutionalized religions (agama) that recognized by the state, and beliefs (aliran kepercayaan), recognized as part of the culture but not recognized as official religions by the state. The first 
religions to be officially acknowledged by the state were Islam and Christianity; Buddhism and Hinduism. As mention earlier, previously there were debates whether or not Confucianism is a religion, but currently it is recognized as a religion by President Abdurrahman Wahid by Presidential Decree Number 6, 2000 to recovate Presidential Instruction Number 14, 1967 on Chinese's Religion, Belief and Culture.

The term religion in Indonesia is translated to agama. This translation does not precisely match. The term agama in Sanskrit means "scripture," as in the Shaiva Agamas, which inspired the Shaiva Siddhanta philosophy that influenced Indonesian Hinduism. In Indonesian language, agama generally means "religion". There are two major sections of the Department of Religion: the Education Office handles curricular issues and teacher training, and the Information Office is a liaison to the public. The Department of Religion has major sections for the six accepted religions. Its Hindu section works through PHDI and the school system (McDaniel, 2010, pp.93-111).

This standardization of Agama Hindu has its implication toward the existence of Hindu community in Indonesia especially on the acknowledging of plurality in Hinduism itself. While in India, it is really flexible, in Indonesia Hinduism has certain standardization.

This research shows us one out of many adjusting process when a certain Hindu community did identification toward The Balinese Hindu, that is accepted the official one. They follow The Balinese Hindu's way of belief do not as an articulation of their acceptance toward this religion, rather than to save their existence being accused as astray.

\subsection{Hare Krishna and Their Politic Of Recognition}

In the social science, there is a theory of recognition. To be recognized means to be accepted as a part of particular person or society. In the social life, the problems on recognition bring some social problems. Charles Taylor provides analytical tools to look at the problem of recognition. He is popular with his article entitled "The Politic of Recognition". According to Taylor, it is important to have social recognition since it links his/her existence to and the community so that people understand who they are, in the middle of society. To some extent society shape our identity since their recognition or its absence could result in a social acceptance in one hand or on the other hand could bring them a danger. This danger has many names such as personal or groups' oppression, misperception, accused as a pervert, and demean of their existence as a human being (Taylor, 1994, pp.25-28)

The process of recognition was a part of the ISKCON movement worldwide, including in Yogyakarta. The ISCKON is a religious movement started by A.C. Bhaktivedanta Swami, 69 years old, in 1965 traveled from Calcutta to New York. He went to spread the teaching of Sri Chaitanya Mahaprabhu (1486-1533) (Rochford, 2005, p. 101) In United State, Hare Krishna underwent a significant improvement in a number of followers since it's in 1967, by the traveled of Prabhupada, the popular name of Bhaktivedanta Swami, in the middle of American, to the emerging hippie community in the Haight-Ashbury section of San Francisco. Thousands of young hippies were migrating to the neighborhood where one of Prabhupada's disciples had rented a storefront. During the first two years, ISKCON recruited an estimated 150 to 200 converts. To hold the countercultural youth being attracted, ISKCON developed a communal structure. From San Francisco, Prabhupada sent his disciples to Los Angeles, Montreal, and England to establish ISKCON communities in the late 1960s. Thereafter, ISKCON communities emerged in major cities worldwide. In 1975, there were thirty-six ISKCON communities and preaching centers in North America, and forty more worldwide. By 1983, the total number spanning the globe had grown to nearly two hundred. In 2003, ISKCON had over three hundred communities and preaching centers. Before his death in 1977, Prabhupada initiated approximately five thousand disciples into his movement worldwide. A large majority of these later disciples defected from ISKCON in the years after Prabhupada's death (Rochford, 2007, p.14).

Bhagavad Gita is the center of their teachings. They believe that Bhagavad Gita is a wisdom for common people differs to Vedas that could not be understood by lay people. To be acknowledged as unique, they made a different translation of Bhagavad Gita. Their translation is always entitled as "Bhagavad Gita as It Is" to be differentiated from others. The significant different of this translation is in the way Krishna regard as the Highest figure. Budi Rahardjo, the leader of ISKCON community in Yogyakarta, said, "There are many translations on Bhagavad Gita, but they always did with such a tendencies and by skip the teaching that Krishna is the highest divine figure." By this concept, Hare Krishna is attracting people to learn on Bhagavad Gita worldwide, including Indonesian.

In 1973, Prabhupada was invited to Indonesia to teach on Bhagavad Gita by Indian Hindus community. He taught in Indonesian Institute of Science (Lembaga Ilmu Pengatuan Indonesia - LIPI) and among Indian 
in Jakarta. He visited Jakarta and met many Indonesian Hindu leaders such as Tjokorda Rai Sudharta and others. Unfortunately, Swami Prabhupada did not well welcome by the leaders of the Hindu Dharma Council of Indonesia (Parisada Hindu Dharma Indonesia - PHDI), The National Council of Hindu in Indonesia, who found his teachings too sectarian (Somvir, 2004, pp.255-263)

Soon afterward, the activities of the Hare Krishna movement were the topic of discussions among Indonesian Hindus. Even if this community was rejected by some leaders, but there was a spreading process done by Gaura Mandala Bhumi das, an Australian artist who came to Indonesia and intended to spread the teaching of Hare Krishna in Indonesia. Prabhupada asked him to come to Indonesia on his visitation to Australia in 1975. Gaura at the time was only $25 \mathrm{yr}$ old. He just finished his study on Biology. On his university period, he had undergone six-month university student exchange to Universitas Gadjah Mada in Yogyakarta, Indonesia. On doing the task from Prabudhapa, in 1978, he arrived in Indonesia and stayed in Rawamangun, Jakarta. Among Hindu community, he is famous on his ability to describe Bhagavad Gita. Together with his four disciples, he promotes the Hare Krishna teaching in Indonesia. They are two siblings from Bali, Peter Jarot from Australia and Budi Rahardjo from Magelang. After having a better understanding of the movement, they become Mr. Gaura's coworkers on spreading this movement in Indonesia up to the present day.

From 1978 to 1984, they translated some of Prabhupada's teachings to Bahasa Indonesia in 13 books about Krishna Consciousness. Some of them are "Jalan Menuju Pada Krishna" (The Path to Krishna), "Bhagavad Gita Jawaban Segala Pertanyaan" (Bhagavad Gita as the answer of any Question), and "Jalan Mudah Menuju Planet Lain" (The Short way to the Other Planet). They sold the books in national bookstores. On each publication, they put their address in case people want to ask them for more information regarding the books or their spiritual journey. Since there are only a view number of publications of Hindu teachings in Bahasa Indonesia, these books were well accepted by the Hindu communities, even they sent their questions to be answered. From this publication and the communication through the letters, this community got its members.

From the first publication, they had already regard PHDI (Parisada Hindu Dharma Indonesia, National Body for Indonesian Hindu) as the significant organization for their existence. On each publication, they always ask for the preface from the PHDI's leader. But, in 1984, all publications were banned since, at that year, the government declared that the ISKCON is not in line to Hindu Teaching. One single verse at the end of Bhagavad Gita that mentions "sarva-dharman parityajya mam ekam saravam vraja. Aham tvam sarvapapebhyo moksyaisyami ma sucah" (Leave all religion (your duty) but come and surrender yourself completely, so that I will liberate you from every sin and I will give you a freedom from every suffering. Don't be afraid). In Indonesian, the word dharman was translated to Agama and this is the source of the problem. By leaving the agama means this Hare Krishna is not in line with Indonesian values that recognized agama. They perceived dharman as a duty, but in fact, the ban has already been there. For this young community, the ban could be a barrier to their existence and this is a problematic one. On the one hand, they believed in the teaching of the movement, on the other hand, they could not ignore the ban from the government. In this particular situation, they had only one option to do an adjustment toward Hindu community. They existed in Indonesia as an underground community. They perceived themselves as a member of The Balinese Hindu in public, but they still kept their Hare Krishna rites.

After a long period of living under Soeharto era, Indonesia started the Reformation era with a more democratic society. It has an impact also on the living of religions in Indonesia. In 2000, President Abdurrahman Wahid accepted Confucianism as one of the official religions. In the Hindu community, there was an improvement on recognition of the plurality of Hindu. On November 5, 2001, there was a deal among Hindu communities to respect one to the other. Since the day, the Hare Krishna Movement is accepted as a member of Indonesian Hindu National Body named Parisada Hindu Dharma Indonesia (PHDI). On January 1, 2002, SAKKHI (Sampradaya Kesadaran Krishna Indonesia) was formed to bridge middle between the growing number of devotees and PHDI. According to Yadav Somvir in 2003, there are more than 1,500 followers of the Hare Krishna Movement in Indonesia. Its leaders still remember the long years during which their organization was formally banned and they congregated in secret. Today the movement enjoys more freedom and is able to appear in public (Somvir, 2004, pp. 255-263). In 2015, evolved to form a legal body and registered itself with the Ministry of Law and Human Rights of the Republic of Indonesia as the "International Society for Krishna Consciousness Association" (ISKCON) (Perkumpulan International Society for Krishna Consciousness, 2017).

In Indonesia, The ISKCON banned at their first decade, but for 27 years they existed. On that period, they did some adjustment as their identity politic process. Budi Rahardjo, one of Gaura's disciple, is the initiator of this movement in Yogyakarta. From 1985 up to present day, Budi Rahardjo intensely promotes the ISKCON as one of spirituality in Indonesia. Since the movement was banned, he could not promote the 
movement publicly. That is why he adjusts himself as a member of The Balinese Hindu community. Even, from 1987 up to the present, Mr. Budi Rahardjo is a Hindu's teachers as a civil servant. Up to 2001, practically he could only maintain his family's beliefs on Hare Krishna. Afterward, they start to do any effort to spread the teaching. On February 21, 2003, he opened his Ashram, a boarding school for the youth of this community or any other persons to learn the spirituality in the Ashram. He finally success open the community that he already planned since early 1990s. The name of the Ashram is Narayana Smrti Ashram Sri Radha Syamasundara Mandir (a boarding house with a temple to remember Krishna). The students who study in the house do double study program. While studying in the public university, they learn also about the spirituality of Krishna, from the books and Budi Rahardjo or some seniors.

Based on the information above, at least there are three negotiations done by the Hare Krishna Community in Yogyakarta on their recognition in the middle of society:

\subsubsection{Identification toward Hare Krishna Community}

Among their community in Ashram, Hare Krishna do five days prayers. Every single day at $7.30 \mathrm{pm}$ they always have their daily learning Bhagavad Gita. They also wear Indian traditional dress on their daily life in the Ashram at least on their prayer time. According to Budi Rahardjo, it is a part of having a close relation to the Hindu's in India. This is also a kind of identity politics since they distinguish themselves from the Balinese Hindu. Linda Nicholson pays attention to this kind of identification. For her, certain performance has meaning on identity. She said, "The dress and habits associated with an older aristocratic elite now became associated not with superior social status but with an effeminate and decadent type of masculinity, one prone to debauchery and the excesses of self-indulgence" (Nicholson, 2008, p.31). For this community, the dress is not only a part of daily life but also a part of self-identification and to differentiate from others.

The other different factors are the presence of statues and pictures of Krishna. On his teachings, Budi Rahardjo always reminds his community members to praise Krishna as the almighty divine figure, which is different from his teaching among Hindu's community both in school or among members of Hindu's congregation in Pura.

On the previous era, his Hindu's congregation members were problematizing his legality on becoming a part of Hindu's rites. But then, since his rites and teaching are following the line of The Balinese Hindu, he is accepted. Up until today, he is part of this Pura. He made an adjustment on his participation on Hindu's rites. He paid attention more to the statue of a Turtle or Padmasana in the temple. On their belief as Hare Krishna, it is a symbol of Krishna. Instead of devoting to Ida Shang Hyang Widhi Wasa, Budi Rahardjo claims that he devotes only to Krishna. That is why he has no hesitation to ask his Ashram's members to join in the prayer in Pura.

\subsubsection{Identification to Hindu Congregation}

From its arrival in Indonesia, Hare Krishna has already identified themselves as Hindu, even the visitation of Prabhupada in Indonesia in the invitation of Indian Hindu people. At the time, they already referred to PHDI to publish their books. That is why they asked for the preface of each book from PHDI leaders. On the era when Hare Krishna was banned by the Indonesian Government through the proposal of PHDI itself, Hare Krishna could only depend on the recognition of Hindu Community. Budi Rahardjo himself came closer to Hindu community. In 1987, he went to one year study of Hindu and later on was accepted as a civil servant to teach on Agama Hindu class. His involvement with the Hindu congregation helps the ISKCON recognition process.

Since the deal in 2001, the ISKCON community still needs to follow the rites in the Balinese Hindu community. As a teacher on Agama Hindu, Budi Rahardjo is undergoing a dilemma. He teaches that the almighty God in Hindu is 'Ida Sang Hyang Widhi Wasa', but actually his belief is only to Krishna as the highest divine figure. He also becomes a part of Pura Jagatnatha Banguntopo di Sorowajan, Banguntapan, Bantul, Yogyakarta, a Balinese Hindu's temple. He is the one who gives the sermon base on the Veda and Bhagavad Gita, even it is not an obligation for a Hare Krishna to participate.

Since 2003, when he opens his Ashram, he always asks his community members to join in the prayer in Pura. With his adjustment of the presence of Krishna in the Padmasana, he helps his community to find the connection between their belief to Krishna and Hindu prayer in Pura. This effort doesn't require or an obligation, but by doing so, Budi Rahardjo and his community members show their bonding to Hindu congregation. 


\subsubsection{Relation to a Broader Society}

According to I Gusti Ngurah Bagus, Hindu community in Indonesia has not any significant role in the middle of Indonesian society especially when we take a look at the much greater achievements of the other religious communities in Indonesia. There emerged questions, especially among the Hindu middle class, as to why the Hindu community is lagging behind. People criticize PHDI for its less role and suggest to simplifying the rituals and improve the teaching on morality by learning tatwa, or philosophy, in order to transform people when they understand their religious doctrines as fully comprehend. They insisted this community to hold the balance between the performance of rituals and the study philosophy and ethics of their Hindu teaching. He mentions also that some of them take recourse in mystic teachings based on bhakti, or personal devotion sects such as the Hare Krishna movement (Bagus, 2005, pp.96-104).

In the middle of this pessimism on Hinduism, Hare Krishna community in Yogyakarta plays a significant role in society. Budi Rahardjo opens his house for those who want to learn about Hindu. According to the guest book in his house, there were some university students who visit them to learn about Buddhism, some Catholic nuns who visit and stay for three days, some interreligious communities who did their activities in the Ashram. For him, it is not a problem since they have the understanding that all divine figures are actually the other personification of Krishna. Peter L. Berger mentions this tendency as the characteristic of religion. He mentions,

"Religion is the human enterprise by which a sacred cosmos is established. Put differently, religion is cosmization in a sacred mode. By sacred means a quality of mysterious and awesome power, other than man and yet related to him, which is believed to reside in certain objects of experience. This quality may be attributed to natural or artificial objects, to animals, or to men, or to the objectivations of human culture. The cosmos posited by religion thus both transcends and includes man" (Berger, 1967, pp. 25-26).

He also adds another explanation, "The sacred cosmos is confronted by a man as an immensely powerful reality other than himself. Yet this reality addresses itself to him and locates his life in an ultimately meaningful order" (Berger, 1967, p.26). In another word, this community opens themselves to correlate to wider society.

Since 2010, Narayana Smrti Ashram Sri Radha Syamasundara Mandir participates on the carnival for Yogyakarta anniversary. Before, Hindu community did not even contribute any performance on the carnival. In the hand of this Ashram, Hindu community feels their proud even if the performance is always in the Hare Krishna style especially on chanting the praise to Hare Krishna, "Hare Krishna Hare Krishna, Krishna Krishna, Hare Hare, Hare Rama Hare Rama, Rama Rama, Hare Hare".

\section{Conclusions}

The recognition problem is a part of the social relation. In Indonesia, Hare Krishna did not accept this recognition as a gift. It is a part of their power struggle. The existence of Hare Krishna in Yogyakarta is a result of a long effort. The effort influences the way they communicate with others; it influences the way they perceive others both as individual and community. As Taylor mentions, there are significant others on this recognition since the recognition are always about dialogue. In term of Hare Krishna, Indonesia, as a nation with its tolerance toward only five (nowadays six) recognized religions, considers as a significant other. They need to adjust their belief to the nearest community that is Hindu. The PHDI as a national council become another significant other. They always need to have a correlation to be acknowledged as a member of Hindu community. It is not an obligation for them to participate on Hindu's teaching or praying, but in the name of their existence, they do these teachings and praying, even if there are some contradictions with their own values.

As a New Religious Movement, Hare Krishna Movement is flexible on its teaching in front of society. They are doing so, in order to be accepted. This is a problem of recognition. I have two arguments on it. On the one hand, there is a tendency for a mix religion, as people called as Syncretism, but on the other hand, there is also a need for such uniqueness. The syncretism comes as the result of the need to be accepted by the wider community. Their existence has no meaning when people do not accept them as a part of society. Furthermore, when they are not in line with Indonesian law, they will have problem with the national authority. On the other hand, they need to be unique in order to promote their additional meaning. That is 
why they always promote Krishna as the highest God upon other personification of God. This is a part of the identity politics. They do not stand against the official religion even if they are raising a particular idea that different to the idea of the official religions.

Nowadays, Hare Krishna is a part of society in Yogyakarta. Their existence is not problematized even if they always need to always regard Hindu (the mainstream one) as their religion in public and adjust some of their rites and teachings to Hindu. Their public recognition could regard as a process of an identity politics. On getting their identity, they need to do negotiation in order to be perceived as normal in the sight of society members.

\section{References}

Bagus, I.G.N. (2005). The parisada hindu dharma Indonesia in a society in transformation: The emergence of conflicts amidst differences and demands. In M. Ramstedt (Eds.). Hinduism in Modern Indonesia. London: Routledge Curzon (pp. 96-104).

Berger, P.L. (1967). The Sacred Canopy: Elements of a sociological theory of religion. New York: A Doubleday Anchor Book, (pp. 25-26).

Gold, A.G., et., al. (2017). Hinduism. In Encyclopedia Brittanica (pp. 1-17).

Hasse, J., Risakotta, B.A., \& Bagir, Z.A. (2011). Diskriminasi negara terhadap agama di Indonesia: Studi atas persoalan posisi hukum Towani Tolotang pasca pengakuan agama resmi. [State discrimination against religion in Indonesia: Study of the position of Towani Tolotang's legal law after the official recognition of religion]. Jurnal Kawistara, 1(2), 180-190. [In Bahasa Indonesia].

Lanus, S. (2014). Puja Tri Sandhyā: Indian mantras recomposed and standardized in Bali. The Journal of Hindu Studies, 7, pp. 243-272.

McDaniel, J. (2010). Agama hindu dharma Indonesia as a new religious movement: Hinduism recreated in the image of Islam. Nova Religio: The Journal of Alternative and Emergent Religions, 14, 93-111.

Nicholson, L. (2008). Identity before Identity Politics. New York: Cambridge University Press (p. 31).

Rochford Jr, E.B. (2005). Family development and change in the hare Krishna movement. In J. R. Lewis \& J. A. Petersen (Eds.). Controversial New Religions. USA: Oxford University Press. (p. 101).

Rochford, E.B. (2007). Hare Krishna Transformed. New York: New York University Press (p. 14).

Somvir, Y. (2004). Cultural and religious interaction between modern India and Indonesia. In M. Ramstedt (Eds.). Hinduism in Modern Indonesia: A Minority Religion between Local, National, and Global Interests. Routledge Curzon. London. (pp. 255-263).

Taylor, C. (1994). Multiculturalism. New Jersey: Princeton University Press, (pp. 25-73).

Perkumpulan International Society for Krishna Consciousness (ISKCON). (2015). How is ISKCON like in Indonesia? 